\title{
Hvorfor laese geologi? - rundspørge blandt de nye studerende
}

\section{Af geolog Ulla V. Hjuler GeologiskNyt}

Hvad får en nyudklækket student til at vælge geologi på Aarhus universitet? Vi har stillet de nye geologi/geoteknologi-studerende 10 spørgsmål.

I år er der startet 22 studerende på Geologisk Institut på Aarhus Universitet - 14 på geologistudiet og 8 på geoteknologistudiet. Geoteknologi er en ny uddannelse på Aarhus Universitet, der kombinerer naturforståelse fra naturvidenskaberne med tekniske videnskaber. Der er specielt fokus på vand og vandkvalitet samt den overfladenære undergrunds historie og store potentialer.

Alle studerende har deltaget i besvarelserne. Hvis den studerende har føjet kommentarer til, er disse nævnt. I svarene til spørgsmålene 8 og 10 afspejler pilene, at de, der har givet et positivt svar, også i en vis udstrækning har givet en uddybende kommentar. Kommentarerne til de enkelte spørgsmål står i vilkårlig rækkefølge.

Vi håber at kunne lave en mere udvidet undersøgelse senere, hvor også studerende fra København deltager - dette kunne vi desværre ikke nå i dette nummer!

Tak til de studerende for deltagelsen. Jens A. Rasmussen vandt ét års abonnement og modtager snarligst sin præmie.

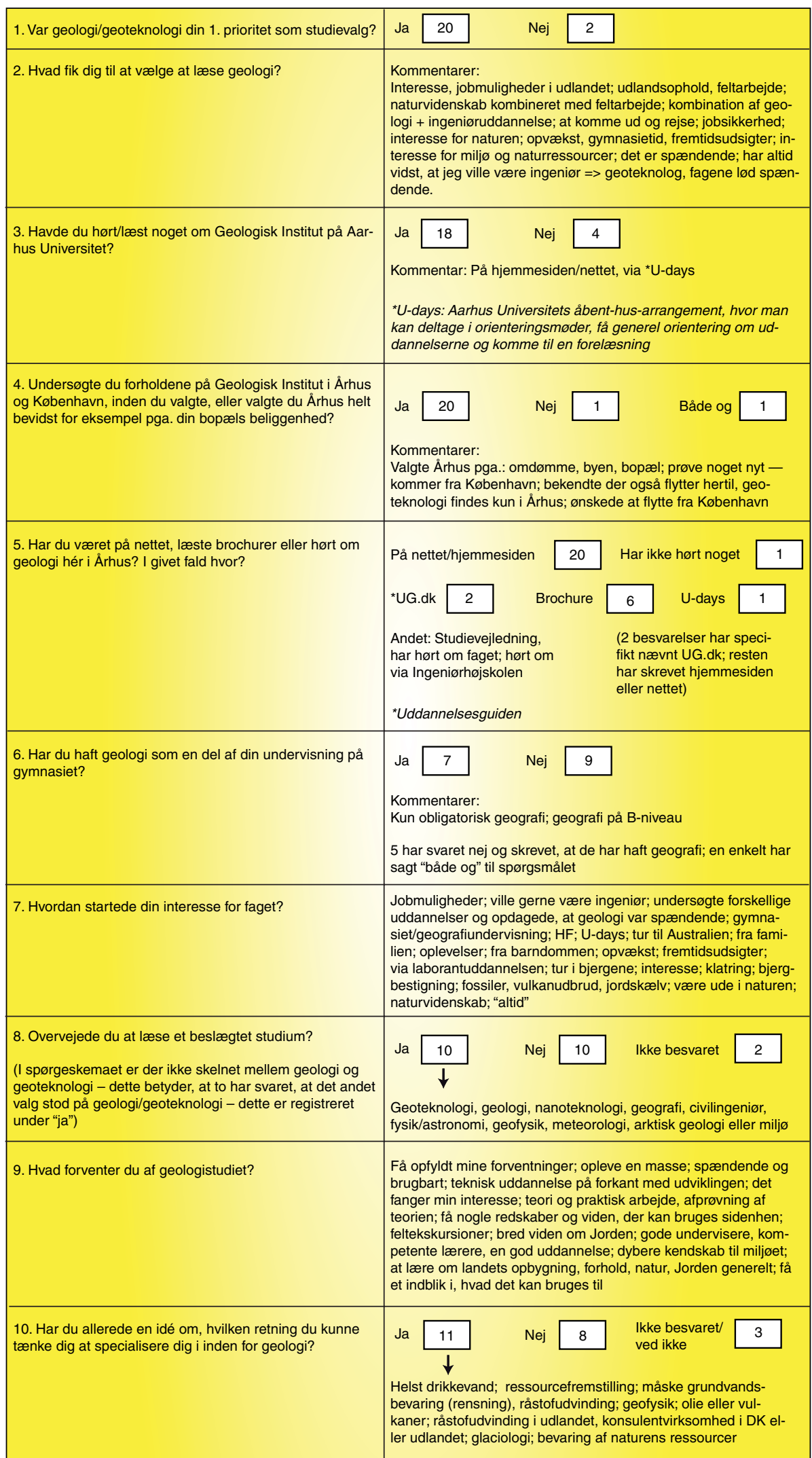

